\title{
Noninvasive genetic sampling of endangered muriqui (Primates, Atelidae): Efficiency of fecal DNA extraction
}

\author{
Paulo B. Chaves ${ }^{1}$, Marcela F. Paes ${ }^{1}$, Sérgio L. Mendes ${ }^{2,5}$, Karen B. Strier ${ }^{3,5}$, Iúri D. Louro ${ }^{4}$ \\ and Valéria Fagundes ${ }^{1,5}$ \\ ${ }^{1}$ Laboratório de Genética Animal, Departamento de Ciências Biológicas, \\ Universidade Federal do Espirito Santo, Vitória, ES, Brazil. \\ ${ }^{2}$ Laboratório de Biologia da Conservação de Vertebrados, Departamento de Ciências Biológicas, \\ Universidade Federal do Espirito Santo, Vitória, ES, Brazil. \\ ${ }^{3}$ Department of Anthropology, University of Wisconsin-Madison, Madison, Wisconsin, USA. \\ ${ }^{4}$ Núcleo de Genética Humana e Molecular, Departamento de Ciências Biológicas, \\ Universidade Federal do Espírito Santo, Vitória, ES, Brazil. \\ ${ }^{5}$ Instituto de Pesquisas da Mata Atlântica, Vitória, ES, Brazil.
}

\begin{abstract}
The muriqui (Brachyteles) is one of the most endangered primates in the world, however little is known about the viability of the remaining populations. We evaluated the technique of extracting DNA from wild muriqui feces for PCR applications. In order to determine the effect of the DNA in subsequent amplifications, we analyzed five different extracts. The importance of the recommended BSA and the HotStarTaq DNA polymerase was tested. The minimal conditions to successfully amplify highly degraded fecal DNA were determined, showing that the recommended reagents are not required. We envision that this method may be useful in further conservation management studies.
\end{abstract}

Keywords: Brachyteles, conservation genetics, endangered species, fecal DNA, noninvasive sampling.

Received: July 27, 2005; Accepted: April 10, 2006.

The genus Brachyteles (muriqui) represents the largest neotropical nonhuman primate and comprises two endemic species occurring in the Brazilian Atlantic Rainforest. The species B. hypoxanthus (Kuhl, 1820) or northern muriqui can be found in the States of Bahia, Minas Gerais and Espírito Santo, and B. arachnoides (É. Geoffroy, 1806) or southern muriqui is distributed along over the States of Rio de Janeiro, São Paulo and Paraná (Aguirre, 1971; Lemos de Sá et al., 1990, Lemos de Sá et al., 1993; Martuscelli et al., 1994). Their small population size and the deforestation of the Atlantic Forest have led to the classification of muriqui as an "endangered" primate since 1982, and as "critically endangered" since 2000 (Rylands et al., 2003). B. hypoxanthus is also listed as one of the 25 most endangered primates of the world since the year 2000 (Mittermeier et al., 2005). Historically, the muriqui species roamed throughout the Atlantic Brazilian Rainforest, but now it is estimated that there are no more than 1200 individuals living in a few dozen remaining forest frag-

Send correspondence to Valéria Fagundes. Laboratório de Genética Animal, Departamento de Ciências Biológicas, Universidade Federal do Espírito Santo, Av Marechal Campos 1468, 29040-090 Maruípe, Vitória, ES, Brazil. E-mail: vfagunde@npd.ufes.br. ments (Strier and Fonseca, 1996/1997). Thus, questions about the consequences of habitat fragmentation in the genetic structure of populations, gene flow and probability of extinction are frequently addressed with regard to muriqui (Leigh and Jungers, 1994; Strier, 1995; Strier, 2000). DNA assessment is critical for investigating these questions, and genotyping for molecular markers like microsatellites is essential to conduct more realistic population viability analyses (PVAs), improving the currently available data (Strier, 1995).

Until recently, molecular genetic analyses of primates have been limited by the availability of blood or tissue samples for DNA extraction (Surridge et al., 2002). Despite the fact that noninvasive DNA sampling usually yields low quantities of DNA (Taberlet et al., 1996; Taberlet et al., 1997; Constable et al., 2001), the advent of the polymerase chain reaction (PCR) technique has been successfully used to assess the genetic composition of social groups and populations, and to evaluate both species and genealogical relationships based on such small samples (Höss et al., 1992; Morin et al., 1994; Constable et al., 1995; Gerloff et al., 1995; Taberlet et al., 1996; Reed et al., 1997; Constable et al., 2001). 
Boom et al. (1990) presented the first study that was successful in isolating DNA from shed epithelial cells mixed with feces. Since then, studies in conservation genetics using DNA from fecal samples have been carried out in threatened species, including bears (Taberlet et al., 1997) and wolves (Creel et al., 2003). In spite of this scenario, in the last few years, fecal samples from muriquis have been used exclusively to monitor ovarian cycle hormones in females, and testosterone and cortisol levels in males (Strier and Ziegler 1997; Ziegler et al., 1997; Strier et al., 1999). In the present study, our primary goal was to test the reliability of results obtained from muriqui fecal DNA by downstream PCR. The conclusions reached may be a starting point for future population genetic studies in this species.

Feces were collected from 28 individually identified muriquis that have been the subjects of long-term observational field research at the "Estação Biológica de Caratinga" (EBC/RPPN-FMA) in Minas Gerais, Brazil. Approximately $5 \mathrm{~g}$ of feces per individual were transferred into a sterile $50 \mathrm{ml}$ polypropylene conical tube containing silica gel beads. About $20 \mathrm{~g}$ of humidity-sensitive silica beads and a fine layer of cotton were placed underneath and above the feces, to completely fill the tubes, in order to isolate and quickly dehydrate the samples. Until DNA extraction, the dehydrated samples were conserved at $4{ }^{\circ} \mathrm{C}$, and the silica beads were changed whenever humidity was detected.

DNA was extracted from $200 \mathrm{mg}$ of dried feces, using the QIAamp DNA Stool Mini Kit (Qiagen) according to the manufacturer's protocol. All procedures were carried out using a face mask. Few extractions were manipulated simultaneously, in order to avoid cross-contamination and contamination by exogenous DNA. Muriquis have a vegetarian diet (Strier, 1991; Olmos et al., 1997), which eliminates the need to remove prey parts, such as bones and hair, as in carnivore fecal extractions (Paxinos et al., 1997; Wasser et al., 1997; Farrell et al., 2000). After extraction, DNA was qualitatively evaluated in $0.8 \%$ agarose gel and quantified in a spectrophotometer (260 nm of wavelength and 1:25 $\mu \mathrm{L}$ of dilution). DNA concentration was calculated as described by Sambrook et al. (1989), and the yields varied from 18 to $140 \mathrm{ng} / \mu \mathrm{L}$. Three of the 28 samples presented DNA concentrations below the detection threshold of the spectrophotometer.

We tested the quality and quantity of the DNA template, and the influence of bovine serum albumin (BSA, New England Biolabs), which has been considered essential in downstream PCR applications using fecal DNA as template, resulting in 90 different amplification mixtures. Five muriqui DNAs with different levels of degradation (quality) in six different quantities (5 ng, $10 \mathrm{ng}, 20 \mathrm{ng}$, $50 \mathrm{ng}, 100 \mathrm{ng}$, and $200 \mathrm{ng}$ ), and three final concentrations of BSA $(0.0,0.1$, and $0.2 \mu \mathrm{g} / \mu \mathrm{L})$, were tested in the PCR mixture.

A total volume of $25 \mu \mathrm{L}$ PCR mixture was used in a PTC-100 Thermocycler (MJ Research), including 10\% of
10X PCR buffer (200 mM Tris- $\mathrm{HCl} \mathrm{pH} \mathrm{8.4,} 500 \mathrm{mM} \mathrm{KCl),}$ $0.2 \mathrm{mM}$ of each dNTP, $2.5 \mathrm{U}$ of "Taq Brazilian Origin" DNA polymerase (Invitrogen), $2.0 \mathrm{mM}$ of $\mathrm{MgCl}_{2}$, and $0.2 \mu \mathrm{M}$ of each primer: L6955 (5'-AACCATTTCATA ACTTTGTCAA-3') and H7766 (5'-CTCTTAATCTTTA ACTTAAAAG-3'). These primers were originally designed to amplify the subunit II of the human cytochrome $c$ oxidase (COII) mtDNA gene (Ashley and Vaughn, 1995), and successfully tested in the closely related genus Ateles (Collins and Dubach, 2000). The PCR conditions included a denaturing phase at $92{ }^{\circ} \mathrm{C}$ for $5 \mathrm{~min}$, followed by $35 \mathrm{cy}-$ cles of $92^{\circ} \mathrm{C}$ for $1 \mathrm{~min}, 48^{\circ} \mathrm{C}$ for $45 \mathrm{~s}$, and $72^{\circ} \mathrm{C}$ for $1 \mathrm{~min}$, and a final extension step at $72{ }^{\circ} \mathrm{C}$ for $5 \mathrm{~min}$. The PCR mix was prepared in a special chamber, to avoid contamination. High-molecular-weight human DNA (200 ng) was used as positive control and distilled water instead of DNA as negative control. All of the 90 reactions were carried out in duplicate, to validate the results. The PCR products of four out of the five muriqui DNAs were sequenced as control (accession numbers DQ118288, DQ118289, DQ118290, DQ118291), to exclude false species-specific amplification from contamination with exogenous DNA (human, plant, protozoa, bacteria and others). The human positive control was also sequenced and deposited in the GenBank (Accession number DQ118287). DNA sequencing was performed in an automated MegaBACE 1000 sequencer, using the DYEnamic ET Dye Terminator Cycle Sequencing Kit (Amersham Biosciences). First, sequences were compared through BLAST on the GenBank database, subsequently they were automatically aligned, and a neighbor-joining tree was drawn using the MEGA 3.0 package (Kumar et al., 2004).

Here, we were able to demonstrate the usefulness of a suboptimal source of DNA such as the feces of the endangered wild muriquis for further PCR applications. We analyzed three variables that could affect the efficiency of PCR using fecal DNA samples: (i) Five DNA qualities; (ii) six DNA quantities $(5 \mathrm{ng}, 10 \mathrm{ng}, 20 \mathrm{ng}, 50 \mathrm{ng}, 100 \mathrm{ng}$, and $200 \mathrm{ng})$; and (iii) three final concentrations of BSA (0.0, 0.1 and $0.2 \mu \mathrm{g} / \mu \mathrm{L}$ ); totaling 90 PCR tests. Only 17 (19\%) of the 90 reactions failed to amplify a COII fragment, indicating a high success rate for mtDNA, with a doubly longer amplicon ( $~ 800 \mathrm{bp})$, as compared to previous analyses of ursids (Wasser et al., 1997).

BLAST query resulted in a $96 \%$ similarity of our four muriqui sequences with Brachyteles arachnoides hypoxanthus (AF216253), 88\% with Ateles paniscus (AF216247), and $87 \%$ with Lagothrix lagothrica (AF216251). The human control sequence crossed with $99 \%$ of human mtDNA. None of the four muriqui sequences showed any similarity with any organisms other than nonhuman neotropical primates. Sequences were also aligned with the complete mtDNA genome of Cebus albifrons (AJ309866), a neotropical primate. The muriqui sequences matched at the correct COII position, which is 
7016-7703 bp (Arnason et al., 2000). The absence of contamination is graphically shown in Figure 1a.

With regard to DNA quality, the most degraded DNA (6* in Figure 1b) presented the lowest amplification efficiency (44\%), but the negative results were obtained almost exclusively in reactions containing 5-20 ng of DNA template. The most intact templates $\left(5^{*}\right.$ and $7^{*}$ in Figure $\left.1 b\right)$ presented $95 \%$ efficiency in amplifying the COII segment. Comparatively, the best results were achieved using non-degraded DNA templates, as observed in extracts $4 *$ $(89 \%), 5^{*}(95 \%)$ and $7 *(95 \%)$.

A minimum of nine out of 15 reactions $(60 \%)$ resulted in positive amplifications when 5-20 ng of DNA template were used. The optimal amount of DNA was found to be above $50 \mathrm{ng}$. Nevertheless, positive amplification was achieved with $5 \mathrm{ng}$, using good quality fecal DNA (e.g., extracts $4^{*}$ and $5^{*}$ ).

In order to test the importance of using BSA, we evaluated the amplification efficiency of all the reactions with at least $50 \mathrm{ng}$ of DNA (optimal amount) and moderately to highly intact DNA (qualities of extracts $4 *, 7^{*}$ and $5^{*}$ ). All
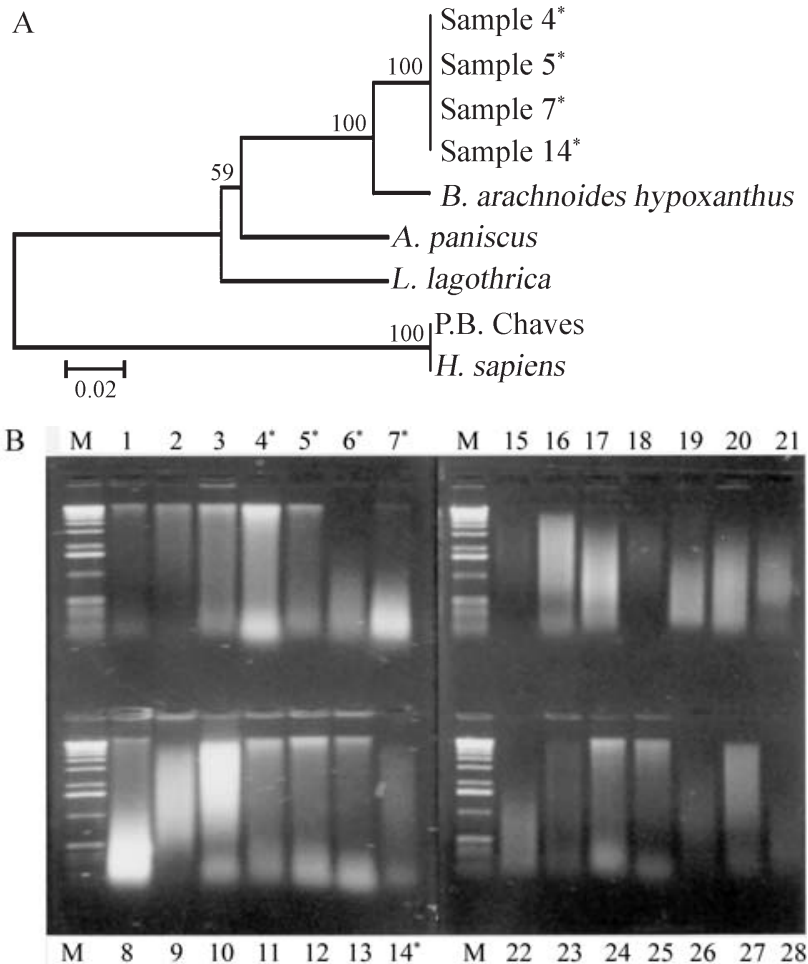

Figure 1 - A. Neighbor-joining tree showing DNA sequences of Brachyteles hypoxanyhus (accession numbers DQ118288, DQ118289, DQ118290 and DQ118291 corresponding to Samples 4*, 5*, 7* and 14*, respectively, this paper) clustered together, and closely related to Brachyteles arachnoides hypoxanthus (AF216253), Ateles paniscus (AF216247) and Lagothrix lagothrica (AF216251). Human control (accession number DQ118287, this paper) is grouped with Homo sapiens (AP008260). Bootstrap values (1000 replicates) are shown above branches B. DNA profiles ( $6 \mu \mathrm{L} /$ lane $)$, numbers correspond to 28 DNA extracts. "M" identifies the $1 \mathrm{~kb}$ ladder. Asterisks refer to samples 4, 5, 6, 7 and 14 used in PCR amplification. of these samples (27/27) showed positive amplifications, suggesting that the concentration of BSA did not affect amplification, under any of the evaluated conditions. Additionally, the results remained practically unchanged after modification of the BSA concentration, when reactions which contained suboptimal amounts of DNA template, such as 5-20 ng, were also counted.

Otherwise, previous studies of other mammals had reported the increasing of the PCR product after addition of BSA (Pääbo, 1990; Kohn and Wayne, 1997; Al-Soud and Rådström, 2000; Palomares et al., 2002). Potentially, BSA can counteract to PCR inhibitors or avoid the adsorption of PCR reagents to the tube wall, making them available to the amplification reaction (P. Taberlet and Qiagen Scientific Support, personal communication). The Qiagen protocol also strongly recommends the addition of BSA to the PCR mixture, in a final concentration of $0.1 \mu \mathrm{g} / \mu \mathrm{L}$.

However, other authors have also reported the dispensability of BSA, or did not report its use (Höss et al., 1992; Takasaki and Takenaka, 1991; Sugiyama et al., 1993; Wasser et al., 1997). Our results imply that despite some studies pointed out that fecal DNA can be contaminated with PCR inhibitors, BSA was not essential in PCR (Farrell et al., 2000; Creel et al., 2003). We believe that in-

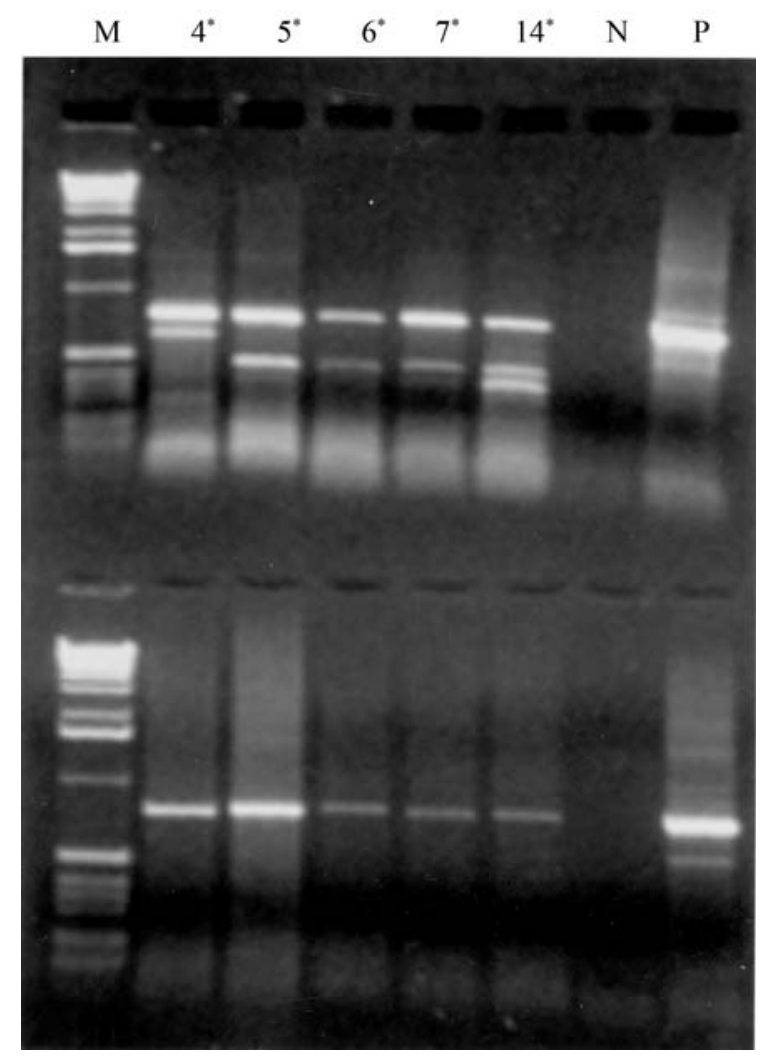

Figure 2 - PCR products of the DNA extracts numbers $4^{*}, 5^{*}, 6^{*}, 7^{*}$, and $14^{*}$, respectively. $\mathrm{N}$ and $\mathrm{P}$ stand for negative and positive controls, respectively. No BSA was added in the reactions, primer concentrations of $0.4 \mu \mathrm{M}$ and $0.2 \mu \mathrm{M}$ were used for upper bands and lower bands, respectively. "M" identifies the $1 \mathrm{~kb}$ ladder. 
hibitors were eliminated during the extraction procedure, and thus the activity of BSA was not significant.

The Qiagen protocol also recommends the use of the Qiagen HotStarTaq DNA polymerase. However we obtained excellent results using a much cheaper polymerase (Brazilian Taq DNA polymerase, Invitrogen Inc). We achieved satisfactory results in minimizing nonspecific PCR bands by reducing the primer concentration from $0.4 \mu \mathrm{M}$ to $0.2 \mu \mathrm{M}$ (Figure 2). Additionally, digestion reactions with endonucleases have shown the suitability of these PCR products for further analysis using Restriction Fragment Length Polymorphisms (Fagundes et al., unpublished data).

Our results provide additional information to optimize the PCR reactions using noninvasive fecal DNA samples as template, minimizing both cost and time of standardization in further genetic studies. In conclusion, appropriate fecal DNA extraction methods make molecular studies feasible for endangered species, such as muriquis. This protocol may also be applicable to a large variety of primate and non-primate mammals in upcoming genetic approaches.

\section{Acknowledgments}

This work was sponsored by Ministério do Meio Ambiente (PROBIO-MMA) and Conselho Nacional de Desenvolvimento Científico e Tecnológico (CNPq). We thanks to Ângela M.S. Perrone and Yuri L.R. Leite for assistance in laboratory procedures and sequencing analysis, to Fernanda P. Paim, Jairo Gomes and Maria Fernanda Iurck for helping in collecting fecal samples, amd to Instituto Brasileiro do Meio Ambiente e dos Recursos Naturais Renováveis (IBAMA) for the collecting license (363/ 2001).

\section{References}

Aguirre AC (1971) O Mono Brachyteles arachnoides (E. Geoffroy). Situação Atual da Espécie no Brasil. Academia Brasileira de Ciências, Rio de Janeiro, 53 pp.

Al-Soud WA and Rådström P (2000) Effects of amplification facilitators on diagnostic PCR in the presence of blood, feces, and meat. J Clin Microbiol 38:4463-4470.

Arnason U, Gullberg A, Burguete AS and Janke A (2000) Molecular estimates of primate divergences and new hypotheses for primate dispersal and the origin of modern humans. Hereditas 133:217-228.

Ashley MV and Vaughn JL (1995) Owl monkeys (Aotus) are highly divergent in cytochrome c oxidase (COII) sequences. Int J Primatol 16:793-806.

Boom R, Sol CJA, Salimans MMM, Jansen CL, Wertheim-van Dillen PM and van der Noordaa J (1990) Rapid and simple method for purification of nucleic acids. J Clin Microbiol 28:495-503.

Collins AC and Dubach JM (2000) Phylogenetic relationships of spider monkeys (Ateles) based on mitochondrial DNA variation. Int J Primatol 21:381-420.
Constable JJ, Packer C, Collins DA and Pusey AE (1995) Nuclear DNA from primate dung. Nature 373:393.

Constable JJ, Ashley MV, Goodall J and Pusey AE (2001) Noninvasive paternity assignment in Gombe chimpanzees. Mol Ecol 10:1279-1300.

Creel S, Spong G, Sands JL, Rotella J, Ziegle J, Joe L, Murphy KM and Smith D (2003) Population size estimation in Yellowstone wolves with error-prone noninvasive microsatellite genotypes. Mol Ecol 12:2003-2009.

Farrell LE, Roman J and Sunquist ME (2000) Dietary separation of sympatric carnivores identified by molecular analysis of scats. Mol Ecol 9:1583-1590.

Gerloff U, Schlötterer C, Rassman K, Rambold I, Hohmann G, Fruth B and Tautz D (1995) Amplification of hypervariable simple sequence repeats (microsatellites) from excremental DNA of wild living Bonobos (Pan paniscus). Mol Ecol 4:515-518.

Höss M, Kohn M, Pääbo S, Knauer F and Schroder W (1992) Excrement analysis by PCR. Nature 359:199.

Kohn MH and Wayne RK (1997) Facts from feces revisited. Trends Ecol Evol 12:223-227.

Kumar S, Tamura K and Nei M (2004) MEGA3: Integrated software for molecular evolutionary genetics analysis and sequence alignment. Brief Bioinform 5:150-163.

Leigh SR and Jungers WL (1994) A re-evaluation of subspecific variation and canine dimorphism in woolly spider monkeys (Brachyteles arachnoides). Am J Phys Anthropol 95:435-442.

Lemos de Sá RM, Pope TR, Glander KE, Struhsaker TT and Fonseca GAB (1990) A pilot study of genetic and morphological variation in the muriqui (Brachyteles arachnoides). Primate Conserv 11:26-30.

Lemos de Sá RM, Pope TR, Struhsaker TT and Glander KE (1993) Sexual dimorphism in canine length of woolly spider monkeys (Brachyteles arachnoides E. Geoffroy 1806). Int J Primatol 14:755-763.

Martuscelli P, Petroni LM and Olmos F (1994) Fourteen new localities for the muriqui (Brachyteles arachnoides). Neotrop Primates 2:12-15.

Mittermeier RA, Valladares-Pádua C, Rylands AB, Eudey AA, Butynski TM, Gazhorn JU, Kormos R, Aguiar JM and Walker S (2005) Primates in Peril: The World's 25 most endangered primates 2004-2006. Conservation International. www.conservation.org/xp/news/press_releases/2005/primates_kit/top252004final.pdf.

Morin PA, Moore JJ, Chakraborty R, Ji L, Goodall J and Woodruff DS (1994) Kin selection, social structure, gene flow, and the evolution of chimpanzees. Science 265:1193-1201.

Olmos F, Franco GADC and Auricchio P (1997) Biometry and stomach contents of some Atlantic Forest primates, with a note on Brachyteles tooth replacement. Neotrop Primates 5:36-39.

Pääbo S (1990) Amplifying ancient DNA. In: Innis MA, Gelfand DH, Sninsky JJ and White TJ (eds) PCR Protocols. Academic Press, San Diego, pp 159-166.

Palomares F, Godoy JA, Pirizs A, O'Brien SJ and Johnson WE (2002) Faecal genetic analysis to determine the presence and distribution of elusive carnivores: Design and feasibility for the Iberian lynx. Mol Ecol 11:2171-2182.

Paxinos E, Mcintosh C, Ralls K and Fleischer R (1997) A noninvasive method for distinguishing among canid species: 
Amplification and enzyme restriction of DNA from dung. Mol Ecol 6:483-486.

Reed JZ, Tollit DJ, Thompson PM and Amos W (1997) Molecular scatology: The use of molecular genetic analysis to assign species, sex and individual identity to seal faeces. Mol Ecol 6:225-234.

Rylands AB, Bampi MI, Chiarello AG, da Fonseca GAB, Mendes SL and Marcelino M (2003) Brachyteles arachnoides. In: IUCN 2004 (ed) 2004 IUCN Red List of Threatened Species. www.redlist.org. Downloaded on 23 July 2005.

Sambrook J, Fritsch EF and Maniatis T (1989) Molecular Cloning. A Laboratory Manual. 2nd edition. Cold Spring Harbor Laboratory Press, New York.

Strier KB (1991) Diet in one group of woolly spider monkeys, or muriquis (Brachyteles arachnoides). Am J Primatol 23:113-126.

Strier KB (1995) Viability analyses of an isolated population of muriqui monkeys (Brachyteles arachnoides): Implications for primate conservation and demography. Primate Conserv $15: 43-52$.

Strier KB (2000) Population viabilities and conservation Implications for muriquis (Brachyteles arachnoides) in Brazil's Atlantic Forest. Biotropica 32:903-913.

Strier KB and Fonseca GAB (1996/1997) The endangered muriqui in Brazil's Atlantic Forest. Primate Conserv 17:131-137.

Strier KB and Ziegler TE (1997) Behavioral and endocrine characteristics of the reproductive cycle in wild muriqui monkeys, Brachyteles arachnoides. Am J Primatol 42:299-310.

Strier KB, Ziegler TE and Wittwert DJ (1999) Seasonal and social correlates of fecal testosterone and cortisol levels in wild male muriquis (Brachyteles arachnoides). Horm Behav 35:125-134.

Sugiyama Y, Kawamoto S, Takenaka O, Kumazaki K and Miwa N (1993) Paternity discriminated and inter-group relationships of chimpanzees at Bossou. Primates 34:545-552.

Surridge AK, Smith AC, Buchanan-Smith HM and Mundy NI (2002) Single-copy nuclear DNA sequences obtained from noninvasively collected primate feces. Am J Primatol 56:185-190.

Taberlet P, Griffin S, Goossens B, Questiau S, Manceau V, Escaravage N, Waits LP and Bouvet J (1996) Reliable genotyping of samples with very low DNA quantities using PCR. Nucleic Acids Res 24:3189-3194.

Taberlet P, Camarra JJ, Griffin S, Uhrès E, Hanotte O, Waits LP, Dubois-Paganon C, Burke T and Bouvet J (1997) Noninvasive genetic tracking of the endangered Pyrenean brown bear population. Mol Ecol 6:869-876.

Takasaki H and Takenaka O (1991) Paternity testing in chimpanzees with DNA amplification from hairs and buccal cells in wadges: A preliminary note. In: Ehara A, Kimura T, Takenaka $\mathrm{O}$ and Iwamoto $\mathrm{M}$ (eds) Primatology Today. Elsevier, Amsterdam, pp 613-616.

Wasser SK, Houston CS, Koehler GM, Cadd GG and Fain SR (1997) Techniques for application of faecal DNA methods to field studies of Ursids. Mol Ecol 6:1091-1097.

Ziegler TE, Santos CV, Pissinatti A and Strier KB (1997) Steroid excretion during the ovarian cycle in captive and wild muriquis, Brachyteles arachnoides. Am J Primatol 42:311-321.

\section{Internet Resources}

GenBank, http://www.ncbi.nih.gov/Genbank/

Associate Editor: Horacio Schneider 